\title{
Non-coding sequence variants define a novel regulatory element in the first intron of the $\mathrm{N}$-acetylglutamate synthase gene.
}

\author{
Johannes Häberle ${ }^{1}$, Barry Moore ${ }^{2}$, Nantaporn Haskins ${ }^{3}$, Véronique Rüfenacht ${ }^{1}$, Dariusz \\ Rokicki $^{4}$, M. Estela Rubio Gozalbo ${ }^{5}$, Mendel Tuchman ${ }^{3}$, Nicola Longo ${ }^{6}$, Mark Yandell ${ }^{7}$, \\ Ashley Andrews ${ }^{6}$, Nicholas AhMew ${ }^{3}$, and Ljubica Caldovic ${ }^{3}$ \\ ${ }^{1}$ University Children's Hospital, Zurich \\ ${ }^{2}$ The University of Utah School of Medicine \\ ${ }^{3}$ Children's National Medical Center \\ ${ }^{4}$ The Children's Memorial Health Institute, \\ ${ }^{5}$ Maastricht University Medical Center \\ ${ }^{6}$ University of Utah \\ ${ }^{7}$ Univ of Utah
}

May 2, 2021

\begin{abstract}
N-acetylglutamate synthase deficiency (NAGSD, MIM \#237310) is an autosomal recessive urea cycle disorder caused either by decreased expression of the NAGS gene or defective NAGS enzyme resulting in decreased production of N-acetylglutamate (NAG), an allosteric activator of carbamylphosphate synthetase 1 (CPS1). NAGSD is the only urea cycle disorder that can be effectively treated with a single drug, N-carbamylglutamate (NCG), a stable NAG analog, which activates CPS1 to restore ureagenesis. We describe three patients with NAGSD due to four novel sequence variants in the NAGS regulatory regions. All three patients had hyperammonemia that resolved upon treatment with NCG. Sequence variants NM_153006.2:c.-3065A $>$ C and NM_153006.2:c-3098C > T reside in the NAGS enhancer, within known HNF1 and predicted glucocorticoid receptor binding sites, respectively. Sequence variants NM_153006.2:c.426+326G >A and NM_153006.2:c.427-218A $>$ C reside in the first intron of NAGS and define a novel NAGS regulatory element that binds retinoic X receptor $\alpha$. Reporter gene assays in HepG2 and HuH-7 cells demonstrated that all four substitutions could result in reduced expression of NAGS. These findings show that analyzing non-coding regions of NAGS and other urea cycle genes can reveal molecular causes of disease and identify novel regulators of ureagenesis.
\end{abstract}

\section{Introduction}

N-acetylglutamate synthase deficiency (NAGSD, MIM\# 237310) is an autosomal recessive urea cycle disorder caused by pathogenic variants in the $\mathrm{N}$-acetylglutamate synthase (NAGS ) gene. Its product, the NAGS enzyme (EC 2.3.1.1) catalyzes formation of N-acetylglutamate (NAG), which is essential for the activity of carbamylphosphate synthetase 1 (CPS1, EC 6.3.4.16), the rate-limiting enzyme of the urea cycle (Waterlow, 1999). NAGSD is the only urea cycle disorder that can be effectively treated with a drug Ncarbamylglutamate (NCG), a stable NAG analog, which binds to and activates CPS1 to completely restore ureagenesis in NAGS deficient patients (Caldovic et al., 2004; Grisolia \& Cohen, 1952, 1953; Haberle, 2011). NAGSD can manifest either within hours after birth if there is complete loss of NAGS function or at any time thereafter in patients with residual NAGS activity. Symptoms of NAGSD include lethargy progressing to coma and death with laboratory studies showing elevated blood ammonia and glutamine, and low citrulline concentrations (Ah Mew \& Caldovic, 2011; Haberle, 2011). 
The human NAGS gene, located on chromosome 17, has seven exons that encode a 534 amino acid protein and a regulatory region that extends at least $3 \mathrm{~kb}$ upstream of the first exon (Caldovic et al., 2002; Elpeleg, Shaag, Ben-Shalom, Schmid, \& Bachmann, 2002; Haberle et al., 2003; Heibel et al., 2011). Expression of the NAGS gene is controlled by the promoter and $-3 \mathrm{~kb}$ enhancer, which were identified based on their conservation in mammalian NAGS genes (Heibel et al., 2011; Heibel et al., 2012). The NAGS promoter binds the transcription factors specificity protein 1 (Sp1), cAMP response element binding (CREB) and farnesoid $\mathrm{X}$ receptor (FXR) (Heibel et al., 2012; Renga et al., 2011). The -3 kb NAGS enhancer binds transcription factors hepatocyte nuclear factor 1 (HNF1) and nuclear factor Y (NF-Y) and directs liver-specific expression of the NAGS gene (Heibel et al., 2012).

The establishment of accurate molecular diagnostic methods for NAGSD is clinically important because the biochemical phenotype cannot be easily differentiated from other proximal urea cycle disorders, but unlike these other disorders, NAGSD can be effectively treated with NCG (Ah Mew \& Caldovic, 2011; Haberle, 2011). Although most of the sequence variants causing NAGSD have been found in the NAGS coding region (Al Kaabi \& El-Hattab, 2016; Caldovic, Morizono, \& Tuchman, 2007; Kim et al., 2015; Sancho-Vaello et al., 2016; van de Logt, Kluijtmans, Huigen, \& Janssen, 2017), three pathogenic variants have been found in the non-coding regions (Heibel et al., 2012; Sonaimuthu et al., 2021; Williams et al., 2018). Therefore, understanding of the NAGS gene regulation and the function of its regulatory elements is essential for confirming the pathological nature of sequence variants found in patients. In this study, we identify a novel regulatory element in the first intron of the $N A G S$ gene based on the sequence variants found in patients with NAGSD and describe two new pathogenic sequence variants in the $-3 \mathrm{~kb}$ enhancer of the NAGS gene.

\section{Materials and Methods}

Case Descriptions

All methods were performed in accordance with the relevant guidelines and regulations of the participating institutions. Mutation analysis was conducted with the approval of the Institutional Review Boards of the University of Utah School of Medicine and the Zurich University Children's Hospital. Informed consent was obtained either from all study subjects or their parents/guardians.

Case 1

The patient, a male, was hospitalized at 25 months of age for vomiting, dehydration, respiratory symptoms and progressive lethargy. He was found to have metabolic acidosis with elevated lactate and ammonia (hyperammonemia at $120 \mu \mathrm{mol} / \mathrm{L}$ on presentation, normal 21-50). Toxicology testing was negative as well as blood and urine cultures. He was admitted to the intensive care unit (ICU) where his ammonia decreased to $43 \mu \mathrm{mol} / \mathrm{L}$ upon administration of intravenous fluids containing glucose and, eventually lipids, with clinical improvements of becoming more alert and engaged. During the initial hospitalization peak ammonia was $185 \mu \mathrm{mol} / \mathrm{L}$. Newborn screening was reviewed and was normal at 1 and 8 days of age, with normal citrulline and glutamine/citrulline ratio. He had history of developmental delays (unable to walk, no words at 25 months of age) and had a previous hospitalization for altered mental status and dehydration with metabolic acidosis at 17 months of age at which time intussusception was suspected (ammonia was not measured at that time). A head computed tomography (CT) was normal. Otherwise, the child was growing normally and had a normal head size.

This child was the product of in vitro fertilization from sperm donor to a healthy mother. He had a 4-year-old half-sister (different sperm donor) with mild speech delay, improving with therapy.

Plasma amino acids showed elevated glutamine (peak $1448 \mu \mathrm{mol} / \mathrm{L}$ on admission, normal 410-700) with mildly low citrulline $(9 \mu \mathrm{mol} / \mathrm{L}$ before supplements, normal 10-60) and arginine at low end of normal $(44 \mu \mathrm{mol} / \mathrm{L}$, normal 40-160). Orotic acid in the urine was mildly increased at $6.2-7.3 \mathrm{mmol} / \mathrm{mol}$ creatinine (normal 0.7 5.1 ) with normal orotidine (1.7-2.4 mmol/mol creatinine, normal $0.7-4.2)$. The child was discharged home on a low protein diet with medical food, citrulline supplements, and glycerol phenylbutyrate. Whole exome sequencing was denied by insurance. Standard genetic testing covering the exons of the OTC, CPS1 ,NAGS 
, and $C A 5 A$ genes did not reveal pathogenic sequence variants.

Despite adherence to therapy, the child continued to have swings in ammonia and elevated glutamine in the plasma amino acids. The child was admitted again to the hospital at 26 months of age because of croup and poor intake leading to hyperammonemia $(179 \mu \mathrm{mol} / \mathrm{L})$. Labs and clinical status normalized with breathing treatment, dextrose containing intravenous fluids and intralipids. In view of the persistent instability, the child was tried on NCG (100 mg/kg per day) that resulted in normalization of ammonia and plasma amino acids. These remained normal even after sequentially stopping glycerol phenylbutyrate, citrulline supplements, amino acid modified medical food and the low protein diet. Clinically, his development started to improve with the initial therapies, including protein restricted diet. At 26 months, he had his first independent step and first word. He was walking independently at 31 months. By 39 months he had >100 words which he began to place in sentences.

\section{Case 2}

The patient was the first son of unrelated Dutch parents, born at 41 weeks of gestation. At day 4 , he had a remarkable tachypnea and lethargy that prompted blood gas analysis. The results showed a respiratory alkalosis $\left(\mathrm{pH} 7.6, \mathrm{CO}_{2} 2.5 \mathrm{kPa}\right)$ and elevated ammonia concentration $(270-309 \mu \mathrm{mol} / \mathrm{L})$. Physical examination revealed no additional abnormalities. A urea cycle defect was suspected; therefore, the patient was referred to a metabolic center and treated with sodium benzoate, an ammonia scavenger medication, dietary protein restriction and later with NCG. Cerebral ultrasound was normal with no signs of edema or intracranial bleeding.

Metabolic investigations revealed highly elevated plasma glutamine (1018 $\mu \mathrm{mol} / \mathrm{L}$, normal 208-294) and low-to-normal plasma citrulline whereas the excretion of orotic acid was normal. This led to the probable diagnosis of NAGSD. Treatment with protein restriction, citrulline supplementation and NCG resulted in normal metabolic profile and clinical condition.

The child developed normally except for an impaired vision due to Leber congenital amaurosis. At present, 7 years old, he attends regular school with the necessary adaptations because of his blindness. His growth is unremarkable. His diet is normal and with adequate NCG medication his amino acid profile is normal.

\section{Case 3}

This patient is a boy, born at term after uneventful pregnancy and delivery. His parents declared nonconsanguinity. The boy's development was normal, although he presented aversion to meat and dairy. At the age of eight years, after a week of dairy-rich diet, he presented to a hospital with symptoms of gastroenteritis, balance problems and qualitative disturbances of consciousness. CNS infection and brain tumor were ruled out and further diagnostic tests revealed rapidly increasing hyperammonemia $(198 \mu \mathrm{mol} / \mathrm{L}$, followed by 281 $\mu \mathrm{mol} / \mathrm{L}$; normal <60), with high concentrations of glutamine in the serum and CSF $(1173 \mu \mathrm{mol} / \mathrm{L}$ and 3033 $\mu \mathrm{mol} / \mathrm{L}$, respectively; normal ranges $152-700$ and $365-700)$, low citrulline concentrations $(11.1 \mu \mathrm{mol} / \mathrm{L}$ in serum and $3.6 \mu \mathrm{mol} / \mathrm{L}$ in CSF; normal ranges $1-55$ and $0-8$, respectively), normal serum but decreased CSF arginine concentrations $(30.9 \mu \mathrm{mol} / \mathrm{L}$ and $13.4 \mu \mathrm{mol} / \mathrm{L}$, respectively; normal ranges $6-187$ and $14.2-$ $25.8)$ and normal ornithine concentrations $(12.8 \mu \mathrm{mol} / \mathrm{L}$ in serum and $16.9 \mu \mathrm{mol} / \mathrm{L}$ in CSF). Urinary organic acids revealed elevated orotic acid $(9.5 \mathrm{mmol} / \mathrm{mol}$ creatinine; normal range $0.08-1.08)$. The treatment with hemodiafiltration was started immediately but the ammonia level remained high $(291 \mu \mathrm{mol} / \mathrm{L})$ and the patient's neurologic status worsened. Administration of sodium benzoate, sodium phenylbutyrate and NCG led to decrease of ammonia concentration to normal levels $(<60 \mu \mathrm{mol} / \mathrm{L})$ within hours and patient status improved rapidly. Biochemical tests done on the third day of treatment revealed almost normal serum glutamine concentration $(530 \mu \mathrm{mol} / \mathrm{L})$ and normal level of orotic acid $(4.80 \mathrm{mmol} / \mathrm{mol}$ creatinine). The low protein diet was implemented, but the patient still required high doses of sodium benzoate, L-arginine (initially intravenously and then orally) and hypercaloric diet to keep ammonia at acceptable levels (70 - $100 \mu \mathrm{mol} / \mathrm{L}$ ). Because laboratory investigations and quick response to treatment with sodium benzoate, sodium phenylbutyrate and NCG suggested NAGSD, therapeutic trial with NCG at a dose of $100 \mathrm{mg} / \mathrm{kg}$ was performed after withdrawal of ammonia scavengers. Ammonia normalized rapidly from $120 \mu \mathrm{mol} / \mathrm{L}$ to 44 
$\mu \mathrm{mol} / \mathrm{L}$ after administration of NCG. Following the start of treatment with NCG at a dose of $15 \mathrm{mg} / \mathrm{kg}$, the patient had no hyperammonemic episodes and is doing well clinically, although he still prefers low-protein diet.

Identification of Patient Sequence Variants

Case 1

DNA was extracted from proband's whole blood and prepared using TruSeq DNA PCR-free libraries (Illumina). The Illumina HiSeq X Ten System (Illumina) was used to sequence the proband's DNA to a median $84 \mathrm{x}$ whole-genome coverage. Sequence reads were aligned to the GRCh37 reference genome (including decoy sequences from the GATK resource bundle) using the BWA-MEM (Li, 2013). The resulting BAM files were de-duplicated, INDEL realignment and base quality recalibration was performed using Picard tools (Toolkit, 2019) followed by the GATK variant discovery toolkit using a best practices workflow (DePristo et al., 2011). Quality control metrics indicated high quality sequence, alignment and variant calling. Sequence variant data for the proband in VCF file format was loaded into the Fabric Genomics (formerly Omicia) platform (https://fabricgenomics.com/), and genes involved in the urea cycle were examined in detail within this framework to identify variants that may have an impact on gene function.

Cases 2 and 3

Sequence analysis of coding exons, including flanking intronic regions, as well as the promoter and enhancer region were carried out as described before (Williams et al., 2018). Sequencing of the regulatory element in the NAGS intron 1 was performed using the BigDye Terminator Cycle Sequencing kit version 1.1 and an ABI 3130 genetic analyzer (Applied Biosystems by Life Technologies Europe BV, Zug, Switzerland) (Williams et al., 2018) after amplification with 5'-gca gga tac gct gcg ggc tc-3' and 5'-gtg ggc cag acg tgg tgc tc-3' primers and following amplification conditions: $15 \mathrm{~min}$ initial denaturation at $95^{\circ} \mathrm{C} ; 38$ cycles of denaturation $(20 \mathrm{~s}$ at $95^{\circ} \mathrm{C}$ ), annealing $\left(20 \mathrm{~s}\right.$ at $\left.58^{\circ} \mathrm{C}\right)$ and extension $\left(1 \mathrm{~min}\right.$ at $\left.72^{\circ} \mathrm{C}\right)$; and a final extension at $72^{\circ} \mathrm{C}$ for $7 \mathrm{~min}$. If not provided, genomic DNA was extracted from peripheral blood leukocytes.

Bioinformatic Analysis

Inspection of the UCSC Genome Browser conservation track within the human NAGS gene (chr17:42,078,702-42,086,453 of the GRCh37/hg19 human genome assembly) revealed an approximately 200 bp-long conserved region within first intron of the NAGS gene (chr17: 42,082,680-42,082,880); this region is contained in a cis -acting conserved regulatory element (chr17:42,082,631-42,082,888) of the cCRE track (Consortium, 2012) of the UCSC Genome Browser. Corresponding genomic regions from 20 mammalian species (Table S1) were downloaded, aligned using Clustal Omega (Sievers et al., 2011) and the alignment was visualized with WebLogo 3 (Crooks, Hon, Chandonia, \& Brenner, 2004). Transcription factors that bind to the conserved element within first intron of the human NAGS gene were identified by data mining the ENCODE project database (Ljubica Caldovic (July 20, 2020)) (Caldovic, 2018). The hepatocyte nuclear factor $4 \alpha$ (HNF4 $\alpha$ ) binding site (chr17:42,082,640-42,082,899 in the GRCh37/hg19 human genome assembly) was identified from Transcription Factor ChIP-seq Clusters track of the UCSC Genome Browser. The retinoic $\mathrm{X}$ receptor $\alpha(\mathrm{RXR} \alpha)$ and Sp1 binding sites were identified based on their similarity with the respective MA0115.1 and MA0079.3 position matrices in the JASPAR database of transcription binding sites (Fornes et al., 2020).

Genomic regions from 24 mammals (Table S2) that correspond to the -3kb enhancer (Heibel et al., 2012) of the human NAGS gene (chr17:42,078,635-42,079,129 of the GRCh37/hg19 human genome assembly) were downloaded, aligned using Clustal Omega (Sievers et al., 2011) and the alignment was visualized with WebLogo 3 (Crooks et al., 2004). Histone modifications of the $-3 \mathrm{~kb}$ enhancer and transcription factors that bind to it were identified by data mining the ENCODE project database (Ljubica Caldovic (July 20, 2020)) (Caldovic, 2018). The glucocorticoid receptor (GR) binding site (chr17:42,078,920-42,078,938 in the GRCh37/hg19 human genome assembly) was identified from the HMR Conserved Transcription Factor Binding Sites track of the UCSC Genome Browser. The HNF4a, RXR $\alpha$, Sp1 and Yin Yang 1 (YY1) 
transcription factor binding sites were identified based on their similarity with the respective MA0114.1, MA1147.1, MA0079.1 and MA0095.2 position matrices in the JASPAR database of transcription binding sites (Fornes et al., 2020).

Plasmid Construction and Expression Studies

Names and inserts of plasmids used in this study are listed in Table 1. Plasmid p4.23hE (Heibel et al., 2011), renamed minP-E in this study (Table 1), was the template for introduction of the NAGS :c.-3065A $>\mathrm{C}$ and $N A G S$ :c-3098C $>$ T sequence changes using mutagenic primers 5'-tcc ctc cga cct ggg act ccg gga c-3' and 5'-gtc ccg gag tcc cag gtc gga ggg a-3' for the c.-3065A $>$ T variant and 5'-cat tga ccc tgg gac cac tgt gtc ccc-3' and 5'-ggg gac aca gtg gtc cca ggg tca atg-3' for the c.-3098C $>$ T variant. Site directed mutagenesis was performed using QuickChange Site-Directed Mutagenesis kit (Agilent Technologies) according to manufacturer's instructions. Resulting plasmids were called c.-3065A $>\mathrm{C}$ and c.-3098C $>\mathrm{T}$ (Table 1), and the presence of the correct sequence changes were verified with DNA sequencing.

Plasmid Prom-Ex1-Int1-Luc (Sonaimuthu et al., 2021) was a template for introduction of the NAGS :c.426+326G $>$ A and c.427-218A $>$ C sequence changes. Mutagenic primers 5'-ccg acc ttg gat tcc ggg aca tct ttg ggg g-3' and 5'-ccc cca aag atg tcc cgg aat cca agg tcg g-3' were used to generate theNAGS :c.426+326G $>$ A sequence change while primers 5'-tcc ctc cga cct ggg act ccg gga c-3' and 5'-gtc ccg gag tcc cag gtc gga ggg a-3' were used for the c.427-218A $>$ C sequence change. The QuickChange Site-Directed Mutagenesis kit (Agilent Technologies) was used to introduce the mutations according to manufacturer's instructions; resulting plasmids were called c.426+326G $>$ A and c.427-218A $>$ C (Table 1) and their correct sequence was verified with DNA sequencing.

Culturing of the HepG2 cells (ATCC) and the HuH-7 cells (Charles Rice laboratory, Rockefeller University), their transfections and reporter assays were carried out as described previously (Sonaimuthu et al., 2021; Williams et al., 2018).

\section{Results}

Non-coding sequence variants found in patients with NAGSD

We have identified three subjects with NAGSD and pathogenic sequence variants in the non-coding regions of the NAGS. Subject 1 is a compound heterozygote for two non-coding sequence variants in the NAGS gene: the $N A G S$ : c. $426+326 \mathrm{G}>\mathrm{A}$ located in the first intron of the $N A G S$ gene and $N A G S$ : c. $-3065 \mathrm{~A}>\mathrm{T}$, located in the $-3 \mathrm{~kb} N A G S$ enhancer and adjacent to the previously identified $N A G S:$ :c-3064C $>$ A pathogenic sequence variant (Heibel et al., 2012). Subject 2 is a compound heterozygote for sequence variants NAGS :c.427-218A >C located in the NAGS intron 1, and NAGS: c.1494G >A or p.Trp498Ter in exon 7, leading to a premature termination of translation at codon 498 (Figure S1). Subject 3 is a homozygote for the sequence variant NAGS: c.-3098C > T (Figure S2), located in the -3kb NAGS enhancer (Heibel et al 2012).

Query of the gnomAD (Karczewski et al., 2020), dbSNP153 (Sherry et al., 2001) and 1000 Genomes Project (Genomes Project et al., 2015) databases indicated that none of the four non-coding sequence variants have been previously reported. The GERP (Cooper et al., 2010; Goode et al., 2010) and phyloP (Siepel et al., 2005) scores of the c.-3065A $>$ T, c.427-218A $>$ C and c.426+326G $>$ A sequence variants indicated that they affected highly conserved base pairs while the base pair affected by the c.-3098C $>\mathrm{T}$ is not as conserved in mammalian genomes (Table 2). However, the phastCons (Siepel et al., 2005) scores of all four sequence variants indicated that they reside within conserved elements of the human genome (Table 2). Functional effect prediction programs Combined Annotation Dependent Depletion (CADD) (Kircher et al., 2014; Rentzsch, Witten, Cooper, Shendure, \& Kircher, 2019) and MutationTaster2 (Schwarz, Rodelsperger, Schuelke, \& Seelow, 2010) indicated that all four sequence variants should be disease causing.

Because phastCons scores of the two intronic sequence variants indicated that they reside in a region of high sequence conservation we used data mining approaches to further characterize this region (Caldovic, 2018). Query of the phastCons conservation track of the UCSC Genome Browser revealed a 200 bp conserved element with genomic coordinates chr17:42,082,680-42,082,799 (GRCh37/hg19 human genome assembly) in 
the first intron of the NAGS gene (Figure 1A). Moreover, based on its biochemical signatures this region was identified as a candidatecis -regulatory element by ENCODE data analysis center (Figures 1A-B and (Consortium, 2012)). The ENCODE Project database was also queried for transcription factors that bind to this region in the human liver. This revealed that the NAGS intronic element binds RXR $\alpha, \mathrm{HNF} 4 \alpha$ and Sp1 transcription factors (Figure 1B). Transcription factor Chip-Seq track of the UCSC Genome Browser was then used to locate more precisely the HNF4 $\alpha$ binding site, while comparisons with the Sp1 and RXR $\alpha$ position similarity matrices from the JASPAR database of transcription factor binding sites (Fornes et al., 2020) were used to locate $\mathrm{Sp} 1$ and $\mathrm{RXR} \alpha$ transcription factor binding sites (Figure 1C). The c.427-218A $>\mathrm{C}$ and c.426+326G $>$ A sequence variants are located within the RXR $\alpha$ binding site and affect base pairs that are highly conserved in mammalian NAGS genes and almost invariant in its canonical recognition sequence (Yang, Subauste, \& Koenig, 1995).

Functional testing of sequence variants in the first intron of the NAGS gene

The pathogenic nature of the two sequence variants found in the first intron of the NAGS gene was confirmed using reporter gene assays in the HuH-7 and HepG2 cell lines. The c.427-218A $>\mathrm{C}$ and c.426+326G $>\mathrm{A}$ sequence variants were introduced into Prom-Ex1-Int1-Luc construct, which harbors luciferase gene fused to the promoter, exon 1 and intron 1 of the human NAGS gene (Table 1). Construct with the wild-type sequence of NAGS intron 1 was used as a control; constructs that contain NAGS promoter controlling expression of either luciferase gene (Prom-Luc; Table 1) or luciferase gene fused to the NAGS exon 1 (Prom-Ex1-Luc; Table 1) were additional controls while construct harboring only luciferase reporter gene was used as a negative control. Luciferase activity was lower in the HuH-7 cells transfected with the Prom-Ex1-Int1 construct harboring the c. $427-218 \mathrm{~A}>\mathrm{C}$ variant while there was a trend $(\mathrm{p}=0.06, \mathrm{n}=9)$ towards lower luciferase activity in in the $\mathrm{HuH}-7$ cells transfected with the construct containing the c.426+326G $>$ A sequence variant (Figure 2A). Luciferase activity was lower in the HuH-7 cells transfected with the Prom-Luc and Prom-Luc-Ex1 constructs compared to the HuH-7 cells transfected with the Prom-Ex1-Int1-Luc construct suggesting that presence of the NAGS intron 1 enhances gene expression in this cell line (Figure 2A). Reporter gene assays in the HepG2 cells revealed that presence of either c.427-218A $>$ C or c. $426+326 \mathrm{G}>\mathrm{A}$ sequence variants caused reduced luciferase activity compared to the HepG2 cells transfected with the Prom-Ex1-Int1-Luc plasmid (Figure 2B). As in the HuH-7 cells, luciferase activity was higher in the HepG2 cells transfected with the Prom-Ex1-Int1-Luc plasmid than in the cells transfected with the Prom-Ex1-Luc construct (Figure 2B). However, luciferase activity was lower in the HepG2 cells transfected with plasmids that contain theNAGS exon 1 coding sequence suggesting that its translation led to decreased expression of the reporter gene in this cell line (Figure 2B). Taken together these data strongly suggest that the conserved element in the first intron of the NAGS gene can enhance its expression and that the c.427-218A $>$ C and c.426+326G $>$ A sequence variants cause NAGSD by reducing expression of the NAGS gene.

Functional testing of sequence variants in the -3kb enhancer of the NAGS gene

Subjects 1 and 3 had deleterious sequence variants in the first intron and coding sequence of their NAGS genes; we used functional testing of the sequence variants found in the $-3 \mathrm{~kb}$ enhancer of their NAGS genes to establish molecular diagnosis of NAGSD. Epigenetic mark H3K27Ac of the NAGS -3 kb enhancer in the human liver indicate active enhancer status while H3K4me3 epigenetic mark, characteristic of active promoters (Kouzarides, 2007), of the $-3 \mathrm{~kb}$ enhancer suggests that it may regulate NAGS gene expression through initiation of enhancer mRNA (Figure 3A) (Natoli \& Andrau, 2012). Query of the ENCODE database revealed that $-3 \mathrm{~kb}$ enhancer harbors conserved GR binding site and binds transcription factors HNF $4 \alpha, \mathrm{RXR}$ $\alpha$, Sp1, and YY1 in addition to previously identified HNF1, NF-Y binding sites (Heibel et al., 2012) and NF1C conserved site (Williams et al., 2018) (Figure 3). The c.-3065A $>$ T sequence variant is located within HNF1 binding site (Figure 3B), one base pair upstream of the previously identified pathogenic NAGS sequence variant (Heibel et al., 2011) while the c.-3098C $>$ T sequence variant resides in the predicted GR binding site (Figure 3B).

Reporter gene assays were used to determine whether c.-3065 $\mathrm{A}>\mathrm{T}$ and c.-3098C $>\mathrm{T}$ sequence variants can affect gene expression in $\mathrm{HuH}-7$ and HepG2 cells. Base pair changes that correspond to the two $-3 \mathrm{~kb}$ 
enhancer variants found in subjects 1 and 3 were introduced into minP-E plasmid (Table 1) followed by transfection of the plasmids into either HuH-7 or HepG2 cells. The minP-E plasmid was used as a positive control; cells transfected with plasmid containing either only minimal promoter or promoter-less plasmid were used as negative controls. Depending on the experiment, luciferase activity increased approximately 8 to 10-fold in the HuH-7 cells and 19 to 29 -fold in the HepG2 cells when -3 kb enhancer was placed upstream of the minimal promoter (Figure 4). Luciferase activity was slightly above background level in the presence of the c.-3065A $>\mathrm{T}$ sequence variant in both $\mathrm{HuH}-7$ and HepG2 cells (Figure 4A-B) strongly suggesting that this sequence variant can have deleterious effect on the NAGS gene expression. In the presence of the c.-3098C $>$ T sequence variant luciferase activity was reduced by approximately one half in the HuH-7 cells and by about two thirds in the HepG2 cells compared to cells expressing plasmid with the wild-type $-3 \mathrm{~kb}$ enhancer (Figure 4C-D). This suggests that the c.-3098C $>$ T sequence variant likely has a negative effect on the $N A G S$ gene expression.

\section{Discussion}

This report describes four new non-coding sequence variants in theNAGS gene that can cause reduced NAGS expression and NAGSD. None of the four sequence variants have been previously reported and all four reduced luciferase activity in reporter gene assays. Two of the sequence variants are located in a conserved region of the first NAGS intron and define a novel regulatory element of theNAGS gene. This novel regulatory element binds transcription factors $\mathrm{HNF} 4 \alpha, \mathrm{RXR} \alpha$ and Sp1 in human liver based on the data from the ENCODE project. First introns of many human genes often harbor regulatory elements based on their conservation in mammalian genomes, presence of DNase hypersensitive sites and epigenetic histone modifications indicative of active regulatory elements (Jo \& Choi, 2019; Park, Hannenhalli, \& Choi, 2014). Several regulatory elements found within first introns bind Sp1 transcription factor (Beaulieu et al., 2011; Bornstein, McKay, Morishima, Devarayalu, \& Gelinas, 1987; Guerin, Leclerc, Verreault, Labrie, \& Luu-The, 1995; Liska, Robinson, \& Bornstein, 1992), similar to the regulatory element within first intron of human $N A G S$ gene identified in this study.

The c.427-218A $>$ C and c.426+326G $>$ A sequence variants both affect highly conserved base pairs in the $\mathrm{RXR} \alpha$ binding site suggesting a role for this transcription factor in the regulation of NAGS expression. Decreased reporter gene activity in cells transfected with constructs containing sequence variants within $\mathrm{RXR} \alpha$ binding site, which is consistent with decreased NAGS expression in patients with the two sequence variants, suggests that $\mathrm{RXR} \alpha$ acts as transcriptional activator of $N A G S . \mathrm{RXR} \alpha$ transcription factor is a nuclear receptor that binds vitamin A metabolites 9-cis -retinoic acid (Evans \& Mangelsdorf, 2014) and 9-cis -13,14-dihydroretinoic acid, which is a better candidate for physiological RXR $\alpha$ ligand because it has been detected in the liver (Krezel, Ruhl, \& de Lera, 2019). RXR $\alpha$ regulates transcription either as a homodimer or heterodimer with retinoic acid receptor, thyroid receptor or vitamin D receptor. Ongoing efforts of the ENCODE project may reveal whether RXR $\alpha$ binds as a homo- or heterodimer to regulatory element in the first intron of humanNAGS gene. There are no reports of regulation of urea cycle enzymes by vitamin D. Both vitamin A and thyroid hormone play a role in the protein metabolism of rats. Vitamin A deficiency results in increased protein catabolism and higher expression of urea cycle genes and enzymes in adult and growing rats (Esteban-Pretel et al., 2010; McClintick et al., 2006). This effect of vitamin A deficiency on expression of urea cycle genes is likely an indirect consequence of increased protein catabolism, does not exclude activation of NAGS expression by RXR $\alpha$ and can be consistent with decreased expression of NAGS due to sequence variants that may decrease binding of receptors for vitamin $\mathrm{A}$ and its metabolites. Manipulation of the thyroid hormone levels in rats affect abundance of urea cycle enzymes, but direction of the change depends on the duration of hypothyroidism and control of food intake by experimental animals. Prolonged hypothyroidism in rats, lasting 4-7 weeks, resulted in increased abundance of urea cycle enzymes and capacity to produce urea probably due to decreased food intake and weight loss in the hypothyroid animals (Marti, Portoles, Jimenez-Nacher, Cabo, \& Jorda, 1988; Silvestri et al., 2006). In a different set of studies, hypothyroidism lasting two weeks led to increased production of urea and urea cycle intermediates, including NAG. However, neither hypo- nor hyperthyroidism led to changes in expression of urea cycle genes in mouse liver (Feng, Jiang, Meltzer, \& Yen, 2000; Flores-Morales et al., 2002) as well as abundance and 
activity of urea cycle enzymes in rat liver (Hayase, Naganuma, Koie, \& Yoshida, 1998; Hayase, Yonekawa, Yokogoshi, \& Yoshida, 1991; Hayase, Yonekawa, \& Yoshida, 1992, 1993; Hayase \& Yoshida, 1995). This suggests that thyroid hormone receptors are unlikely to regulate expression of $N A G S$ by forming heterodimers with $\operatorname{RXR} \alpha$.

Two of the sequence variants were found in the $-3 \mathrm{~kb}$ enhancer of the NAGS gene. We queried ENCODE project database for epigenetic marks found in this region in the human liver. Acetylation of the lysine 27 of the histone $\mathrm{H} 3$ in this region indicates that it is an active enhancer of the human NAGS gene. The lysine 4 of the histone $\mathrm{H} 3$ is tri-methylated in the $-3 \mathrm{~kb}$ enhancer. Although this epigenetic mark indicates active promoters, many enhancers can bind RNA polymerase II and initiate transcription of enhancer RNA (eRNA) (Natoli \& Andrau, 2012). Closer inspection of the Transcription Factor ChIP-Seq track of the UCSC Genome Browser revealed that RNA polymerase II binds to the -3 kb NAGS enhancer in HepG2 cells and likely initiates transcription of an eRNA from this region. This may explain the inability of the $-3 \mathrm{~kb}$ enhancer to act in the orientation independent manner (Heibel et al., 2012).

The c.-3065A $>$ T sequence variant affects a base pair that is highly conserved in mammals and located in the HNF1 transcription factor binding site. Negative effect of the c.-3065A > T sequence variant on HNF1 binding to the $-3 \mathrm{~kb}$ enhancer is a likely explanation for the deleterious effect of this variant. A sequence variant that reduces binding of HNF1 to $-3 \mathrm{~kb}$ enhancer and located immediately downstream of the c.-3065A $>\mathrm{T}$ was found in a patient with NAGSD (Heibel et al., 2011). Two pathogenic sequence variants found in the HNF1 binding site of the $-3 \mathrm{~kb}$ enhancer stress the importance of this transcription factor for expression of the $N A G S$ gene and normal ureagenesis.

The second variant found in the $-3 \mathrm{~kb}$ enhancer is located in the predicted GR binding site. This variant reduced luciferase activity presumably through reduced binding of GR to its binding site in the $-3 \mathrm{~kb}$ enhancer. Circadian fluctuations of glucocorticoid secretion regulate expression of urea cycle genes and enzymes during feeding and fasting periods to accommodate removal of excess ammonia that is released as amino acids enter gluconeogenesis (Luna-Moreno, Garcia-Ayala, \& Diaz-Munoz, 2012). The role of glucocorticoids in regulation of ureagenesis was revealed through decreased abundance and activity of urea cycle enzymes in adrenalectomized rats (Hazra, DuBois, Almon, Snyder, \& Jusko, 2008; McLean \& Gurney, 1963). GR binds to regulatory elements and activates expression of the rat Cps1 gene (Christoffels et al., 1998; Christoffels et al., 2000; Christoffels, van den Hoff, Moorman, \& Lamers, 1995; Schoneveld, Gaemers, Hoogenkamp, \& Lamers, 2005). Regulation of other urea cycle genes by GR is indirect and requires ongoing protein synthesis of transcription factors that directly regulate rat ornithine transcarbamylase, argininosuccinate synthetase 1, argininosuccinate lyase and arginase 1 (Gebhardt \& Mecke, 1979; Lin, Snodgrass, \& Rabier, 1982; Morris \& Kepka-Lenhart, 2002; Nebes \& Morris, 1988; Ulbright \& Snodgrass, 1993). A role for GR in regulation of ureagenesis in humans is supported by the observation of abnormal concentrations of urea cycle intermediates and low urea concentration in the blood of patients with Addison's disease (Okun et al., 2015) and in patients receiving prednisolone treatment (Wolthers, Hamberg, Grofte, \& Vilstrup, 2000). NAGSD in one of our patients and functional tests of the c.-3098C $>\mathrm{T}$ variant, located in the predicted GR binding site, suggest that GR might directly regulateNAGS expression. Unfortunately, the data about GR binding to DNA in human liver are not yet available in the ENCODE database.

Molecular diagnosis of NAGSD is important because it is the only urea cycle disorder that can be effectively treated with a drug (Caldovic et al., 2004; Haberle, 2011). Two sequence variants found in the first intron define a new NAGS regulatory element that binds and implicates transcription factors HNF4 $\alpha$ and RXR $\alpha$ in the regulation of $N A G S$ expression and ureagenesis. The four non-coding sequence variants that cause $N A G S$ deficiency reported here bring the total number of non-coding, disease-causing NAGS variants to seven, which is almost $14 \%$ of deleterious NAGS sequence variants (Al Kaabi \& El-Hattab, 2016; BijarniaMahay et al., 2018; Cartagena et al., 2013; Cavicchi et al., 2018; Heibel et al., 2011; van de Logt et al., 2017; Williams et al., 2018). This underscores the importance of analyzing both coding and non-coding regions of the NAGS gene, which is amenable to both Sanger and next generation sequencing, for the presence of disease-causing sequence variants. 


\section{Acknowledgements}

This work was supported by Public Health Service Grant R01DK064913 from the National Institutes of Health, Recordati Rare Diseases, Inc, and the Rashid Family Foundation. Work on urea cycle disorders is supported by the Swiss National Science Foundation (grant 320030_176088 to JH). Mutation analysis for NAGSD at the Zurich laboratory is supported by Recordati Rare Diseases. Whole genome sequencing of DNA from case 1 was supported by the Utah Genome project. We are grateful for the support and resources from the Center for High Performance Computing at the University of Utah for computational analysis of case 1 .

\section{Conflicts of Interest}

Mutation analysis (Dr. Häberle and Ms. Rüfenacht) for cases 2 and 3 and functional testing of the four non-coding variants (Dr. Caldovic and Ms. Haskins) were supported by the Recordati Rare Diseases, Inc. that manufactures and sells NCG as Carbaglu ${ }^{\circledR}$ (carglumic acid), which is used for treatment of NAGS deficiency.

\section{Author Contributions:}

Barry Moore, MS - coordinated WGS, led alignment and variant calling steps and performed genomic analysis to identify candidate variants for patient 1 .

Mark Yandell, PhD critically reviewed the manuscript.

Nicola Longo, MD PhD, and Ashley Andrews, NP - identified patient 1, performed NCG testing, arranged for genetic testing, collected clinical history, wrote it, and critically revised the manuscript.

Dariusz Rokicki, MD - identified patient 3, performed NCG testing, arranged for genetic testing, collected and wrote clinical history, and critically revised the manuscript.

Estela Rubio, MD - identified patient 2, performed NCG testing, arranged for genetic testing, collected and wrote clinical history, and critically revised the manuscript.

Véronique Rüfenacht - NAGS gene sequencing.

Nantaporn Haskins - prepared reporter gene constructs and carried out functional testing of the sequence variant.

Mendel Tuchman, MD - critically revised the manuscript.

Johannes Häberle, MD - wrote the manuscript and supervised NAGSgene sequencing.

Nicholas AhMew, MD - critically revised the manuscript.

Ljubica Caldovic, $\mathrm{PhD}$ - performed bioinformatic analysis of NAGSregulatory regions, wrote the manuscript and supervised functional testing.

\section{Data Sharing}

The data that support the findings of this study are available in the supplementary material of this article

\section{Figure Legends}

Figure 1. Sequence variants in the novel regulatory element in the $N A G S$ intron 1 . A. The phastCons track of the UCSC Genome Browser showing conserved regions in the NAGS gene (top) and map of the NAGS gene (bottom) showing genomic region chr17:42,081,993 - 42,086,412 of the GRCh37/hg19 human genome assembly with exons as gray boxes, introns as gray lines and predicted cis -acting conserved regulatory element in the NAGS intron 1 as purple box. B. Genomic region chr17:42,082,368-42,083,068 of the GRCh37/hg19 human genome assembly. Results of the ENCODE ChIP-Seq experiments showing binding of transcription factors HNF $4 \alpha$ (blue), RXR $\alpha$ (orange) and Sp1 (green) to NAGS intron 1 in the human liver tissue (top) and phastCons track of the UCSC Genome Browser showing conserved region within NAGS 
intron 1 (bottom) .C. LOGO alignment of the conserved intronic sequences from 20 mammals. Magenta - pathogenic sequence variants. Blue $-\mathrm{HNF} 4 \alpha$ binding site. Orange $-\mathrm{RXR} \alpha$ binding site. Green $-\mathrm{Sp} 1$ binding site.

Figure 2. Functional testing of the sequence variants found in NAGS intron 1 from patients with NAGSD. Relative luciferase activity in HuH-7 (A) and HepG2 (B) cells transfected with the promoter-less plasmid pGL4.10[luc2 ] (Bkgd), plasmid with NAGS promoter controlling luciferase expression (Prom-Luc), plasmid with NAGS promoter controlling luciferase fused to the coding sequence of $N A G S$ exon 1 (Prom-Ex1-Luc), plasmid with $N A G S$ promoter controlling luciferase fused to the NAGSexon and intron 1 (Prom-Ex1-Int1-Luc) and plasmids with intronic mutations found in patients with NAGS deficiency (c.427-218A $>$ C and c.426+326G $>$ A). Data represent mean \pm SEM of $n=9$ measurements. ${ }^{* *}$ indicate $\mathrm{p}<0.01, * * * *$ indicates $\mathrm{p}<0.0001$.

Figure 3. Sequence variants in the $-3 \mathrm{~kb}$ enhancer of the $N A G S$ gene. A. Genomic region chr17:42,078,635-42,079,129 of the GRCh37/hg19 human genome assembly. Results of the ENCODE ChIPSeq experiments showing histone modifications (top) and binding of transcription factors HNF4 $\alpha$ (blue), $\mathrm{RXR} \alpha$ (orange), Sp1 (green) and YY1 (purple) to -3kb enhancer in the human liver tissue (bottom) .B. LOGO alignment of the -3kb enhancer sequences from 25 mammals. Confirmed HNF1 and NF-Y binding sites are highlighted in yellow. Conserved GR and NF1C binding sites are highlighted in gray. Magenta pathogenic sequence variants reported here. Dark blue - location of the previously reported c.-3026C $>\mathrm{T}$ and c.-3064C $>$ A sequence variants. Blue $-\mathrm{HNF} 4 \alpha$ binding site. Orange $-\mathrm{RXR} \alpha$ binding site. Green $-\mathrm{Sp} 1$ binding site. Purple - YY1 binding site.

Figure 4. Functional testing of the sequence variants found in the $N A G S-3 \mathrm{~kb}$ enhancer from patients with NAGSD. Effect of the c.-3065A $>$ T sequence variant on luciferase gene expression was tested in HuH-7 (A) and HepG2 (B)cells. Effect of the c.-3098C $>$ T sequence variant on luciferase gene expression was tested in HuH-7 (C) and HepG2(D) cells. Cells were transfected with the promoter-less plasmid pGL4.10[luc2 ] (Bkgd), plasmid with minimal eukaryotic promoter controlling luciferase expression (minP), plasmid harboring -3kb NAGS enhancer and minimal promoter controlling luciferase expression (minP_E), and plasmids with enhancer mutations found in patients with NAGS deficiency (c.-3065A $>$ T and c.-3098C $>$ T). Data represent mean \pm SEM of $\mathrm{n}=9$ measurements. ${ }^{*}$ indicate $\mathrm{p}<0.05,{ }^{*} * *$ indicate $\mathrm{p}<0.001$, $* * * *$ indicate $\mathrm{p}<0.0001$.

\section{References}

Ah Mew, N., \& Caldovic, L. (2011). N-acetylglutamate synthase deficiency: an insight into the genetics, epidemiology, pathophysiology, and treatment. Appl Clin Genet, 4 , 127-135. doi:10.2147/TACG.S12702

Al Kaabi, E. H., \& El-Hattab, A. W. (2016). N-acetylglutamate synthase deficiency: Novel mutation associated with neonatal presentation and literature review of molecular and phenotypic spectra. Mol Genet Metab Rep, 8 , 94-98. doi:10.1016/j.ymgmr.2016.08.004

Beaulieu, E., Green, L., Elsby, L., Alourfi, Z., Morand, E. F., Ray, D. W., \& Donn, R. (2011). Identification of a novel cell type-specific intronic enhancer of macrophage migration inhibitory factor (MIF) and its regulation by mithramycin. Clin Exp Immunol, 163 (2), 178-188. doi:10.1111/j.1365-2249.2010.04289.x

Bijarnia-Mahay, S., Haberle, J., Jalan, A. B., Puri, R. D., Kohli, S., Kudalkar, K., . . . Verma, I. C. (2018). Urea cycle disorders in India: clinical course, biochemical and genetic investigations, and prenatal testing. Orphanet J Rare Dis, 13 (1), 174. doi:10.1186/s13023-018-0908-1

Bornstein, P., McKay, J., Morishima, J. K., Devarayalu, S., \& Gelinas, R. E. (1987). Regulatory elements in the first intron contribute to transcriptional control of the human alpha 1(I) collagen gene.Proc Natl Acad Sci U S A, 84 (24), 8869-8873. doi:10.1073/pnas.84.24.8869

Caldovic, L. (2018). Data mining approaches for understanding of regulation of expression of the urea cycle genes. In F. Uchiumi (Ed.), Gene Expression and Control . Croatia: IntechOen. 
Caldovic, L., Morizono, H., Daikhin, Y., Nissim, I., McCarter, R. J., Yudkoff, M., \& Tuchman, M. (2004). Restoration of ureagenesis in $\mathrm{N}$-acetylglutamate synthase deficiency by $\mathrm{N}$-carbamylglutamate. J Pediatr, 145 (4), 552-554.

Caldovic, L., Morizono, H., Gracia Panglao, M., Gallegos, R., Yu, X., Shi, D., . . Tuchman, M. (2002). Cloning and expression of the human N-acetylglutamate synthase gene. Biochem Biophys Res Commun, 299 (4), 581-586.

Caldovic, L., Morizono, H., \& Tuchman, M. (2007). Mutations and polymorphisms in the human Nacetylglutamate synthase (NAGS) gene.Hum Mutat, 28 (8), 754-759.

Cartagena, A., Prasad, A. N., Rupar, C. A., Strong, M., Tuchman, M., Ah Mew, N., \& Prasad, C. (2013). Recurrent encephalopathy: NAGS (N-acetylglutamate synthase) deficiency in adults. Can J Neurol Sci, 40 (1), 3-9.

Cavicchi, C., Chilleri, C., Fioravanti, A., Ferri, L., Ripandelli, F., Costa, C., . . . Morrone, A. (2018). Late-Onset N-Acetylglutamate Synthase Deficiency: Report of a Paradigmatic Adult Case Presenting with Headaches and Review of the Literature. Int J Mol Sci, 19 (2). doi:10.3390/ijms19020345

Christoffels, V. M., Grange, T., Kaestner, K. H., Cole, T. J., Darlington, G. J., Croniger, C. M., \& Lamers, W. H. (1998). Glucocorticoid receptor, C/EBP, HNF3, and protein kinase A coordinately activate the glucocorticoid response unit of the carbamoylphosphate synthetase I gene. Mol Cell Biol, 18 (11), 6305-6315.

Christoffels, V. M., Habets, P. E., Das, A. T., Clout, D. E., van Roon, M. A., Moorman, A. F., \& Lamers, W. H. (2000). A single regulatory module of the carbamoylphosphate synthetase I gene executes its hepatic program of expression. J Biol Chem, 275 (51), 40020-40027. doi:10.1074/jbc.M007001200 [pii]

Christoffels, V. M., van den Hoff, M. J., Moorman, A. F., \& Lamers, W. H. (1995). The far-upstream enhancer of the carbamoyl-phosphate synthetase I gene is responsible for the tissue specificity and hormone inducibility of its expression. J Biol Chem, 270 (42), 24932-24940.

Consortium, E. P. (2012). An integrated encyclopedia of DNA elements in the human genome. Nature, 489 (7414), 57-74. doi:10.1038/nature11247

Cooper, G. M., Goode, D. L., Ng, S. B., Sidow, A., Bamshad, M. J., Shendure, J., \& Nickerson, D. A. (2010). Single-nucleotide evolutionary constraint scores highlight disease-causing mutations. Nat Methods, 7 (4), 250-251. doi:10.1038/nmeth0410-250

Crooks, G. E., Hon, G., Chandonia, J. M., \& Brenner, S., E. (2004). WebLogo: a sequence logo generator. Genome Res., 14 (6), 1188-1190.

DePristo, M. A., Banks, E., Poplin, R., Garimella, K. V., Maguire, J. R., Hartl, C., . . Daly, M. J. (2011). A framework for variation discovery and genotyping using next-generation DNA sequencing data.Nat Genet, 43 (5), 491-498. doi:10.1038/ng.806

Elpeleg, O., Shaag, A., Ben-Shalom, E., Schmid, T., \& Bachmann, C. (2002). N-acetylglutamate synthase deficiency and the treatment of hyperammonemic encephalopathy. Ann Neurol, 52 (6), 845-849.

Esteban-Pretel, G., Marin, M. P., Cabezuelo, F., Moreno, V., Renau-Piqueras, J., Timoneda, J., \& Barber, T. (2010). Vitamin A deficiency increases protein catabolism and induces urea cycle enzymes in rats. J Nutr, 140 (4), 792-798. doi:10.3945/jn.109.119388

Evans, R. M., \& Mangelsdorf, D. J. (2014). Nuclear Receptors, RXR, and the Big Bang. Cell, 157 (1), 255-266. doi:10.1016/j.cell.2014.03.012

Feng, X., Jiang, Y., Meltzer, P., \& Yen, P. M. (2000). Thyroid hormone regulation of hepatic genes in vivo detected by complementary DNA microarray. Mol Endocrinol, 14 (7), 947-955. doi:10.1210/mend.14.7.0470 
Flores-Morales, A., Gullberg, H., Fernandez, L., Stahlberg, N., Lee, N. H., Vennstrom, B., \& Norstedt, G. (2002). Patterns of liver gene expression governed by TRbeta. Mol Endocrinol, 16 (6), 1257-1268. doi:10.1210/mend.16.6.0846

Fornes, O., Castro-Mondragon, J. A., Khan, A., van der Lee, R., Zhang, X., Richmond, P. A., . . Mathelier, A. (2020). JASPAR 2020: update of the open-access database of transcription factor binding profiles. Nucleic Acids Res, 48 (D1), D87-D92. doi:10.1093/nar/gkz1001

Gebhardt, R., \& Mecke, D. (1979). Permissive effect of dexamethasone on glucagon induction of urea-cycle enzymes in perifused primary monolayer cultures of rat hepatocytes. Eur J Biochem, 97 (1), 29-35.

Genomes Project, C., Auton, A., Brooks, L. D., Durbin, R. M., Garrison, E. P., Kang, H. M., . . Abecasis, G. R. (2015). A global reference for human genetic variation. Nature, 526 (7571), 68-74. doi:10.1038/nature15393

Goode, D. L., Cooper, G. M., Schmutz, J., Dickson, M., Gonzales, E., Tsai, M., . . . Sidow, A. (2010). Evolutionary constraint facilitates interpretation of genetic variation in resequenced human genomes. Genome Res, 20 (3), 301-310. doi:10.1101/gr.102210.109

Grisolia, S., \& Cohen, P. P. (1952). The catalytic role of carbamyl glutamate in citrulline biosynthesis. $J$ Biol Chem, 198 (2), 561-571.

Grisolia, S., \& Cohen, P. P. (1953). Catalytic role of of glutamate derivatives in citrulline biosynthesis. $J$ Biol Chem, 204 (2), 753-757.

Guerin, S. L., Leclerc, S., Verreault, H., Labrie, F., \& Luu-The, V. (1995). Overlapping cis-acting elements located in the first intron of the gene for type I 3 beta-hydroxysteroid dehydrogenase modulate its transcriptional activity. Mol Endocrinol, 9 (11), 1583-1597. doi:10.1210/mend.9.11.8584035

Haberle, J. (2011). Role of carglumic acid in the treatment of acute hyperammonemia due to Nacetylglutamate synthase deficiency. Ther Clin Risk Manag, 7 , 327-332. doi:10.2147/TCRM.S12703

Haberle, J., Schmidt, E., Pauli, S., Kreuder, J. G., Plecko, B., Galler, A., . . Koch, H. G. (2003). Mutation analysis in patients with N-acetylglutamate synthase deficiency. Human Mutation, 21 (6), 593-597.

Hayase, K., Naganuma, Y., Koie, M., \& Yoshida, A. (1998). Role of N-acetylglutamate turnover in urea synthesis by rats treated with the thyroid hormone. Biosci Biotechnol Biochem, 62 (3), 535-539.

Hayase, K., Yonekawa, G., Yokogoshi, H., \& Yoshida, A. (1991). Triiodothyronine administration affects urea synthesis in rats. J Nutr, 121 (7), 970-978. doi:10.1093/jn/121.7.970

Hayase, K., Yonekawa, G., \& Yoshida, A. (1992). Changes in liver concentration of N-acetylglutamate and ornithine are involved in regulating urea synthesis in rats treated with thyroid hormone. $J$ Nutr, 122 (5), 1143-1148.

Hayase, K., Yonekawa, G., \& Yoshida, A. (1993). Arginine affects urea synthesis in rats treated with thyroid hormone. J Nutr, 123 (2), 253-258.

Hayase, K., \& Yoshida, A. (1995). Role of ornithine in urea synthesis in rats treated with thyroid hormone. Biosci Biotechnol Biochem, 59 (5), 801-804.

Hazra, A., DuBois, D. C., Almon, R. R., Snyder, G. H., \& Jusko, W. J. (2008). Pharmacodynamic modeling of acute and chronic effects of methylprednisolone on hepatic urea cycle genes in rats. Gene Regul Syst Bio, 2, 1-19.

Heibel, S. K., Ah Mew, N., Caldovic, L., Daikhin, Y., Yudkoff, M., \& Tuchman, M. (2011). Ncarbamylglutamate enhancement of ureagenesis leads to discovery of a novel deleterious mutation in a newly defined enhancer of the NAGS gene and to effective therapy. Hum Mutat, 32 (10), 1153-1160. doi:10.1002/humu.21553 
Heibel, S. K., Lopez, G. Y., Panglao, M., Sodha, S., Marino-Ramirez, L., Tuchman, M., \& Caldovic, L. (2012). Transcriptional regulation of N-acetylglutamate synthase. PLoS One, 7 (2), e29527. doi:10.1371/journal.pone.0029527

Illumina. Illumina. Retrieved from https://www.illumina.com/

Jo, S. S., \& Choi, S. S. (2019). Analysis of the Functional Relevance of Epigenetic Chromatin Marks in the First Intron Associated with Specific Gene Expression Patterns. Genome Biol Evol, 11 (3), 786-797. doi:10.1093/gbe/evz033

Karczewski, K. J., Francioli, L. C., Tiao, G., Cummings, B. B., Alfoldi, J., Wang, Q., . . MacArthur, D. G. (2020). The mutational constraint spectrum quantified from variation in 141,456 humans. Nature, 581 (7809), 434-443. doi:10.1038/s41586-020-2308-7

Kim, J. H., Kim, Y. M., Lee, B. H., Cho, J. H., Kim, G. H., Choi, J. H., \& Yoo, H. W. (2015). Short-term efficacy of N-carbamylglutamate in a patient with N-acetylglutamate synthase deficiency. J Hum Genet, 60 (7), 395-397. doi:10.1038/jhg.2015.30

Kircher, M., Witten, D. M., Jain, P., O'Roak, B. J., Cooper, G. M., \& Shendure, J. (2014). A general framework for estimating the relative pathogenicity of human genetic variants. Nat Genet, 46 (3), 310-315. doi:10.1038/ng.2892

Kouzarides, T. (2007). Chromatin modifications and their function.Cell, 128 (4), 693-705. doi:10.1016/j.cell.2007.02.005

Krezel, W., Ruhl, R., \& de Lera, A. R. (2019). Alternative retinoid X receptor (RXR) ligands. Mol Cell Endocrinol, 491 , 110436. doi:10.1016/j.mce.2019.04.016

Li, H. (2013). Aligning sequence reads, clone sequences and assembly contigs with BWA-MEM . arXiv. Retrieved from https://arxiv.org/abs/1303.3997

Lin, R. C., Snodgrass, P. J., \& Rabier, D. (1982). Induction of urea cycle enzymes by glucagon and dexamethasone in monolayer cultures of adult rat hepatocytes. J Biol Chem, 257 (9), 5061-5067.

Liska, D. J., Robinson, V. R., \& Bornstein, P. (1992). Elements in the first intron of the alpha 1(I) collagen gene interact with Sp1 to regulate gene expression. Gene Expr, 2 (4), 379-389.

Luna-Moreno, D., Garcia-Ayala, B., \& Diaz-Munoz, M. (2012). Daytime restricted feeding modifies $24 \mathrm{~h}$ rhythmicity and subcellular distribution of liver glucocorticoid receptor and the urea cycle in rat liver. $\mathrm{Br} J$ Nutr, 108 (11), 2002-2013. doi:10.1017/S0007114512000268

Marti, J., Portoles, M., Jimenez-Nacher, I., Cabo, J., \& Jorda, A. (1988). Effect of thyroid hormones on urea biosynthesis and related processes in rat liver. Endocrinology, 123 (5), 2167-2174.

McClintick, J. N., Crabb, D. W., Tian, H., Pinaire, J., Smith, J. R., Jerome, R. E., \& Edenberg, H. J. (2006). Global effects of vitamin A deficiency on gene expression in rat liver: evidence for hypoandrogenism. $J$ Nutr Biochem, 17 (5), 345-355. doi:10.1016/j.jnutbio.2005.08.006

McLean, P., \& Gurney, M. W. (1963). Effect of adrenalectomy and of growth hormone on enzymes concerned with urea synthesis in rat liver.Biochem $J, 87,96-104$.

Morris, S. M., Jr., \& Kepka-Lenhart, D. (2002). Hormonal induction of hepatic mitochondrial ornithine/citrulline transporter mRNA.Biochem Biophys Res Commun, 294 (4), 749-752. doi:10.1016/S0006291X(02)00549-1

Natoli, G., \& Andrau, J. C. (2012). Noncoding transcription at enhancers: general principles and functional models. Annu Rev Genet, 46 , 1-19. doi:10.1146/annurev-genet-110711-155459 
Nebes, V. L., \& Morris, S. M., Jr. (1988). Regulation of messenger ribonucleic acid levels for five urea cycle enzymes in cultured rat hepatocytes. Requirements for cyclic adenosine monophosphate, glucocorticoids, and ongoing protein synthesis. Mol Endocrinol, 2 (5), 444-451.

Okun, J. G., Conway, S., Schmidt, K. V., Schumacher, J., Wang, X., de Guia, R., . . Rose, A. J. (2015). Molecular regulation of urea cycle function by the liver glucocorticoid receptor. Mol Metab, 4 (10), 732-740. doi:10.1016/j.molmet.2015.07.006

Park, S. G., Hannenhalli, S., \& Choi, S. S. (2014). Conservation in first introns is positively associated with the number of exons within genes and the presence of regulatory epigenetic signals. BMC Genomics, 15, 526. doi:10.1186/1471-2164-15-526

Renga, B., Mencarelli, A., Cipriani, S., D'Amore, C., Zampella, A., Monti, M. C., . . Fiorucci, S. (2011). The nuclear receptor FXR regulates hepatic transport and metabolism of glutamine and glutamate.Biochim Biophys Acta, 1812 (11), 1522-1531. doi:10.1016/j.bbadis.2011.06.009

Rentzsch, P., Witten, D., Cooper, G. M., Shendure, J., \& Kircher, M. (2019). CADD: predicting the deleteriousness of variants throughout the human genome. Nucleic Acids Res, 47 (D1), D886-D894. doi:10.1093/nar/gky1016

Sancho-Vaello, E., Marco-Marin, C., Gougeard, N., Fernandez-Murga, L., Rufenacht, V., Mustedanagic, M., . . Haberle, J. (2016). Understanding N-Acetyl-L-Glutamate Synthase Deficiency: Mutational Spectrum, Impact of Clinical Mutations on Enzyme Functionality, and Structural Considerations. Hum Mutat, 37 (7), 679-694. doi:10.1002/humu.22995

Schoneveld, O. J., Gaemers, I. C., Hoogenkamp, M., \& Lamers, W. H. (2005). The role of proximalenhancer elements in the glucocorticoid regulation of carbamoylphosphate synthetase gene transcription from the upstream response unit. Biochimie, 87 (11), 1033-1040. doi:S0300-9084(05)00121-5 [pii]10.1016/j. biochi.2005.02.015

Schwarz, J. M., Rodelsperger, C., Schuelke, M., \& Seelow, D. (2010). MutationTaster evaluates diseasecausing potential of sequence alterations. Nat Methods, 7 (8), 575-576. doi:10.1038/nmeth0810-575

Sherry, S. T., Ward, M. H., Kholodov, M., Baker, J., Phan, L., Smigielski, E. M., \& Sirotkin, K. (2001). dbSNP: the NCBI database of genetic variation. Nucleic Acids Res, 29 (1), 308-311. doi:10.1093/nar/29.1.308

Siepel, A., Bejerano, G., Pedersen, J. S., Hinrichs, A. S., Hou, M., Rosenbloom, K., . . Haussler, D. (2005). Evolutionarily conserved elements in vertebrate, insect, worm, and yeast genomes. Genome Res, 15 (8), 1034-1050. doi:gr.3715005 [pii]10.1101/ gr.3715005

Sievers, F., Wilm, A., Dineen, D., Gibson, T. J., Karplus, K., Li, W., . . Higgins, D. G. (2011). Fast, scalable generation of high-quality protein multiple sequence alignments using Clustal Omega. Mol Syst Biol, $7,539$. doi:10.1038/msb.2011.75

Silvestri, E., Moreno, M., Schiavo, L., de Lange, P., Lombardi, A., Chambery, A., . . Goglia, F. (2006). A proteomics approach to identify protein expression changes in rat liver following administration of 3,5,3'triiodo-L-thyronine. J Proteome Res, 5 (9), 2317-2327. doi:10.1021/pr0601411

Sonaimuthu, P., Senkevitch, E., Haskins, N., Uapinyoying, P., McNutt, M., Morizono, H., . . Caldovic, L. (2021). Gene delivery corrects N-acetylglutamate synthase deficiency and enables insights in the physiological impact of L-arginine activation of N-acetylglutamate synthase. Sci Rep, 11 (1), 3580. doi:10.1038/s41598021-82994-8

Toolkit, P. (2019). Picard Toolkit. Broad Institute, GitHub Repository. Retrieved from http://broadinstitute.github.io/picard/

Ulbright, C., \& Snodgrass, P. J. (1993). Coordinate induction of the urea cycle enzymes by glucagon and dexamethasone is accomplished by three different mechanisms. Arch Biochem Biophys, 301 (2), 237-243. 
van de Logt, A. E., Kluijtmans, L. A., Huigen, M. C., \& Janssen, M. C. (2017). Hyperammonemia due to Adult-Onset N-Acetylglutamate Synthase Deficiency. JIMD Rep, 31 , 95-99. doi:10.1007/8904_2016_565

Waterlow, J. C. (1999). The mysteries of nitrogen balance.Nutrition Research Reviews, 12 , 25-54.

Williams, M., Burlina, A., Rubert, L., Polo, G., Ruijter, G. J. G., van den Born, M., . . Caldovic, L. (2018). N-Acetylglutamate Synthase Deficiency Due to a Recurrent Sequence Variant in the N-acetylglutamate Synthase Enhancer Region. Sci Rep, 8 (1), 15436. doi:10.1038/s41598-018-33457-0

Wolthers, T., Hamberg, O., Grofte, T., \& Vilstrup, H. (2000). Effects of budesonide and prednisolone on hepatic kinetics for urea synthesis.J Hepatol, 33 (4), 549-554. doi:10.1034/j.1600-0641.2000.033004549.x

Yang, Y. Z., Subauste, J. S., \& Koenig, R. J. (1995). Retinoid X receptor alpha binds with the highest affinity to an imperfect direct repeat response element. Endocrinology, 136 (7), 2896-2903. doi:10.1210/endo.136.7.7789315

Table 1. Reporter gene constructs used in this study.

\begin{tabular}{|c|c|c|c|}
\hline Plasmid Name & Plasmid Backbone & $\begin{array}{l}\text { Inserted } N A G S \\
\text { sequence }\end{array}$ & $\begin{array}{l}\text { Genomic } \\
\text { coordinates of the } \\
\text { inserted } N A G S \\
\text { sequence }^{\S}\end{array}$ \\
\hline Prom-Luc $^{+}$ & pGL4.10[luc2] & $N A G S$ promoter & $\begin{array}{l}\operatorname{chr} 17: 42,081,288- \\
42,082,038\end{array}$ \\
\hline Prom-Ex1-Luc & pGL4.10[luc2] & $\begin{array}{l}\text { NAGS promoter, exon } \\
1 \text { coding sequence }\end{array}$ & $\begin{array}{l}\text { chr17:42,081,288- } \\
42,082,457\end{array}$ \\
\hline Prom-Ex1-Int1-Luc & pGL4.10[luc2] & $\begin{array}{l}N A G S \text { promoter, exon } \\
1 \text { coding sequence, } \\
\text { intron } 1\end{array}$ & $\begin{array}{l}\text { chr17:42,081,288- } \\
42,083,010\end{array}$ \\
\hline c. $426+326 \mathrm{G}>\mathrm{A}$ & Prom-Ex1-Int1-Luc & $\begin{array}{l}N A G S \text { promoter, exon } 1 \\
\text { coding sequence, mutated } \\
\text { intron } 1\end{array}$ & $\begin{array}{l}\operatorname{chr} 17: 42,081,288- \\
42,083,010 \\
\operatorname{chr} 17: 42,082,783 \mathrm{G}>\mathrm{A}^{\mathbb{I}}\end{array}$ \\
\hline c. $427-218 \mathrm{~A}>\mathrm{C}$ & Prom-Ex1-Int1-Luc & $\begin{array}{l}N A G S \text { promoter, exon } 1 \\
\text { coding sequence and } \\
\text { mutated intron } 1\end{array}$ & $\begin{array}{l}\operatorname{chr} 17: 42,081,288- \\
42,083,010 \\
\operatorname{chr} 17: 42,082,787 \mathrm{~A}>\mathrm{C}^{\mathbb{I}}\end{array}$ \\
\hline $\min \mathrm{P}^{++}$ & pGL4.23[luc2/minP] & None & None \\
\hline $\min P \_E$ & pGL4.23[luc2/minP] & $N A G S$-3kb enhancer & $\begin{array}{l}\text { chr17:42,078,635- } \\
42,079,129\end{array}$ \\
\hline c. $-3098 \mathrm{C}>\mathrm{T}$ & $\min P \_E$ & $\begin{array}{l}\text { Mutated NAGS -3kb } \\
\text { enhancer }\end{array}$ & $\begin{array}{l}\text { chr17:42,078,635- } \\
42,079,129 \\
\text { chr:42,078,934C> }>\mathrm{T}^{\#}\end{array}$ \\
\hline c. $-3065 \mathrm{~A}>\mathrm{T}$ & $\operatorname{minP}{ }_{-} \mathrm{E}$ & $\begin{array}{l}\text { Mutated NAGS -3kb } \\
\text { enhancer }\end{array}$ & $\begin{array}{l}\text { chr17:42,078,635- } \\
42,079,129 \\
\text { chr:42,078,967A> } \mathrm{T}^{\#}\end{array}$ \\
\hline
\end{tabular}


Table 2. Conservation scores and predicted effects of sequence variants found in patients with NAGS deficiency.

\begin{tabular}{llllll}
\hline Variant & $\begin{array}{l}\text { Conservation } \\
\text { Score }\end{array}$ & $\begin{array}{l}\text { Conservation } \\
\text { Score }\end{array}$ & $\begin{array}{l}\text { Conservation } \\
\text { Score }\end{array}$ & $\begin{array}{l}\text { Predicted } \\
\text { Effect }\end{array}$ & $\begin{array}{l}\text { Predicted } \\
\text { Effect }\end{array}$ \\
\hline GERP & $\begin{array}{l}\text { PhyloP } \\
100 W^{+}\end{array}$ & $\begin{array}{l}\text { PhastCons } \\
100 \mathrm{Way}^{\S}\end{array}$ & CADD C-score & Mutation Taster \\
c.-3098C $>\mathrm{T}^{\mathbb{I}}$ & 3.98 & 0.22 & 0.998 & 16.2 & $\begin{array}{l}\text { Disease } \\
\text { Causing }\end{array}$ \\
c.-3065A $>\mathrm{T}$ & 4.51 & 3.53 & 0.984 & 20.2 & $\begin{array}{l}\text { Disease } \\
\text { Causing } \\
\text { Disease } \\
\text { Causing } \\
\text { Disease } \\
\text { Causing }\end{array}$ \\
\hline
\end{tabular}

${ }^{+}$GERP scores range between -12.36 and 6.18 .

${ }^{++}$PhyloP100Way scores range between -20 and 7.532 .

§PhastCons100Way scores range between 0 and 1.

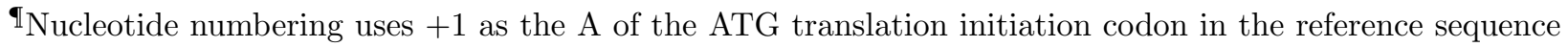
NM_153006.2

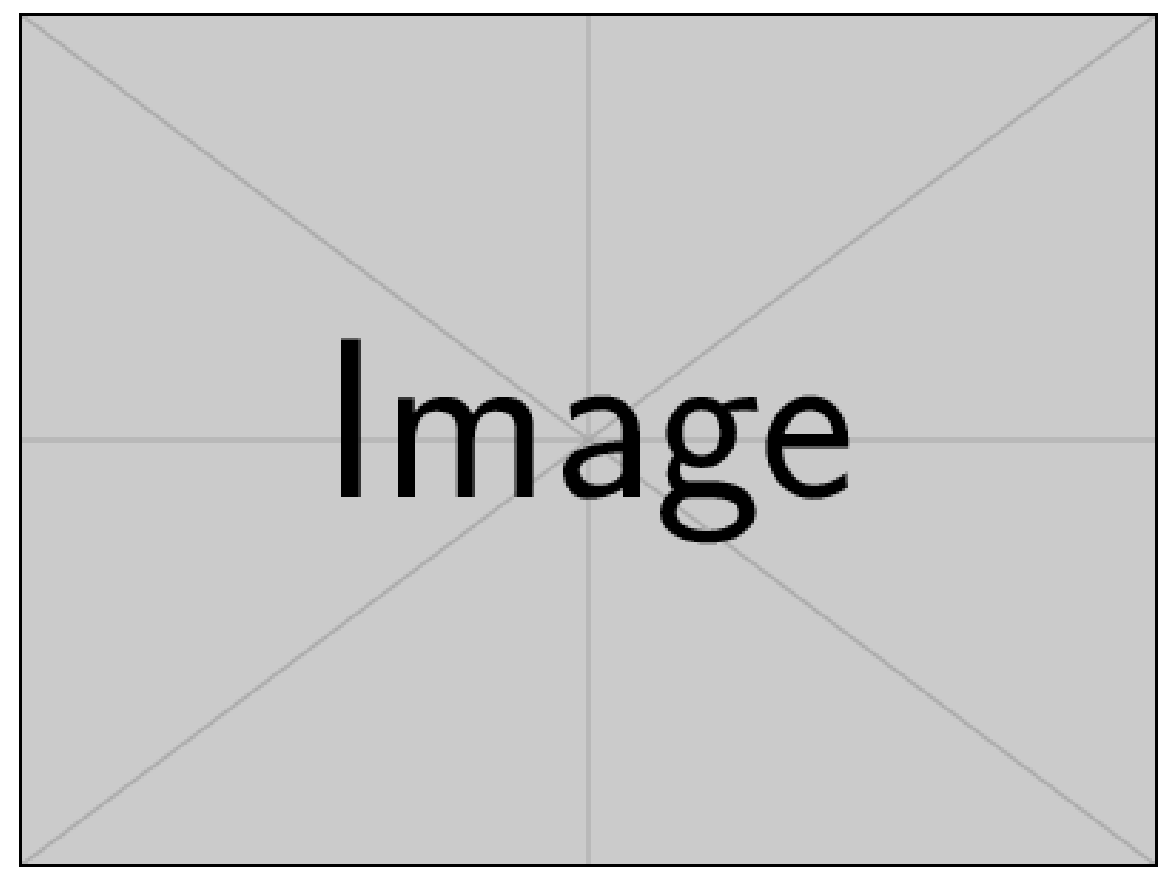




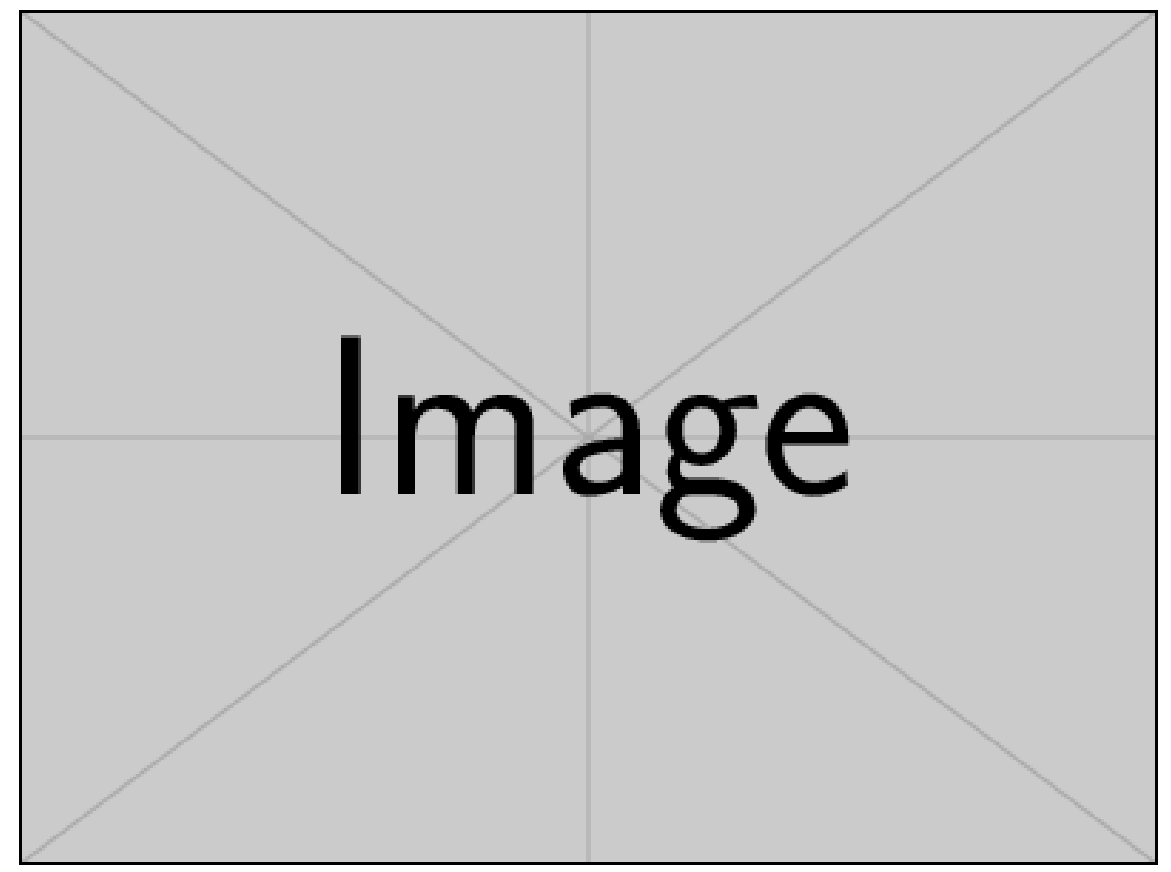

A.
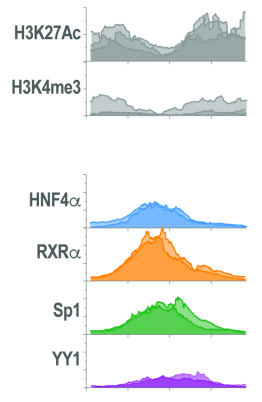

B.

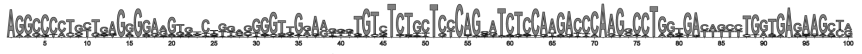

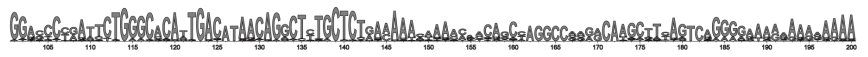

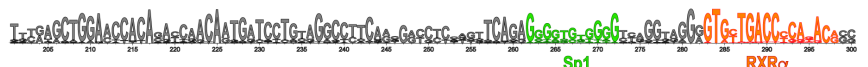

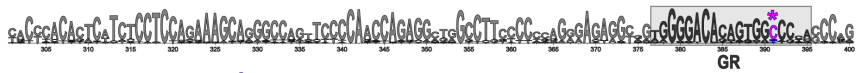

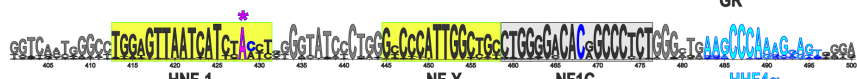

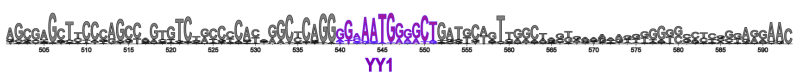




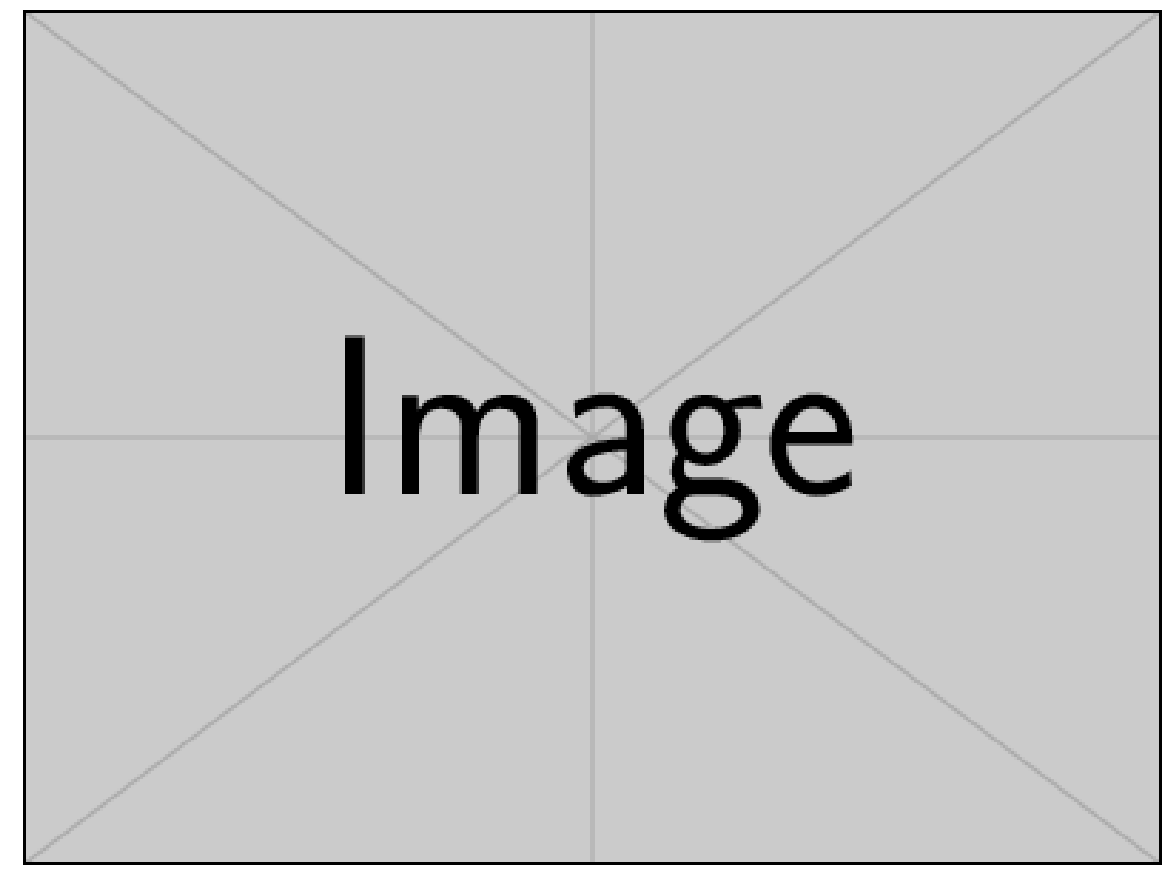

